\title{
Paraoxonase 3: Structure and Its Role in Pathophysiology of Coronary Artery Disease
}

\author{
Kumari Priyanka ${ }^{1,2, *}$, Surjit Singh ${ }^{3, *}$ and Kirandip Gill ${ }^{1}$ \\ 1 Department of Biochemistry, Postgraduate Institute of Medical Education and Research, Chandigarh 160012, \\ India; Kdgill2002@yahoo.co.in \\ 2 Departments of Immunopathology, Postgraduate Institute of Medical Education and Research, \\ Chandigarh 160012, India \\ 3 Department of Internal Medicine, Postgraduate Institute of Medical Education and Research, \\ Chandigarh 160012, India \\ * Correspondence: ku.priyanka@gmail.com (K.P.); surjit51@hotmail.com (S.S.); \\ Tel.: +91-172-2756672 (S.S.); Fax: +91-0172-2744401 (S.S.)
}

Received: 8 September 2019; Accepted: 15 November 2019; Published: 3 December 2019

check for updates

\begin{abstract}
Spanning three decades in research, Paraoxonases (PON1) carried potential of dealing with neurotoxicity of organophosphates entering the circulation and preventing cholinergic crisis. In the past few years, the Paraoxonase multigene family (PON1, PON2, PON3) has been shown to play an important role in pathogenesis of cardiovascular disorders including coronary artery disease (CAD). The PON genes are clustered in tandem on the long arm of human chromosome 7 $(q 21,22)$. All of them have been shown to act as antioxidants. Of them, PON3 is the least studied member as its exact physiological substrate is still not clear. This has further led to limitation in our understanding of its role in pathogenesis of CAD and development of the potential therapeutic agents which might modulate its activity, expression in circulation and tissues. In the present review, we discuss the structure and activity of human PON3 enzyme and its Single nucleotide variants that could potentially lead to new clinical strategies in prevention and treatment of CAD.
\end{abstract}

Keywords: Paraoxonase 3; polymorphisms; PON3 activity; statinase; coronary artery disease; HDL

\section{Introduction}

Cardiovascular diseases (CVDs) are the foremost cause of worldwide mortality, including India, and by 2020 coronary artery disease (CAD) is expected to become the largest contributor to this growing burden [1,2].

Ethnic and regional variations prevail for risk factors of developing CVD. Asian Indians are three to four times more susceptible of developing CVD than Caucasians, six times more than Chinese, and 20 times higher than Japanese [3,4]. Moreover, Indians are prone to develop CAD at a younger age $[5,6]$. Atherosclerosis is considered to be the fundamental pathogenetic mechanism for causation of multi-factorial CAD [7]. The common modifiable risk factors are dyslipidemia, hypertension, smoking, and sedentary lifestyle whereas non-modifiable risk factors are age, gender, and genetics [8]. For development of atherosclerosis, low density lipoprotein-cholesterol (LDL-C) is the major target for oxidation as oxidized LDL-C is involved in both its initiation as well asin progression [9,10].

Research over time has shown a definite role of genetic factors in susceptibility to CAD and significant advances have been made in identifying potential candidate genes which predispose individuals towards the disease. These genes have been identified by different strategies such as linkage studies, association studies with candidate genes, and whole genome wide association [11]. Epidemiology demonstrates an inverse relationship between CAD risk and high-density lipoprotein- 
cholesterol (HDL-C) concentration [12,13]. Studies governing preventive mechanism of CAD have shown that HDL-C exhibits its antioxidant role due to its association with a crucial esterase i.e., paraoxonase [14] besides platelet activating factor acetyl hydrolase [15] and lecithin cholesterol acyl transferase [16]. Paraoxonases are a family of three enzymes, with lipolactonase activity, that degrade lipoperoxides in lipoproteins and cells. These three enzymes share overlapping properties with some differences and gene encoding these enzymes harbors polymorphisms which mask their catalytic activity [14,17]. In context of population genetics, the measurement of Paraoxonase activity and concentration (PON status) are considered to be more important than studying PON polymorphisms alone [17] when the role of these genes is dissected to determine any association with the progression of disease. Studies are lacking in various ethnic groups who have different $P O N$ polymorphisms [18]. The present review discusses the available information on less investigated PON3 status i.e., activity and concentration and its genetic polymorphisms and their possible role in CAD.

\section{Paraoxonases (PONs)}

Remarkable evidence has been produced in the past two decades about the role of paraoxonases in atherosclerosis. PON1 (E.C. 3.1.8.1) was the first identified paraoxonase to play a role in CAD. It hydrolyzes diazinon, chlorpyrifos (an oxon metabolite) and nerve gases [19] (e.g., sarin and soman). It is an HDL-associated enzyme synthesized mainly in the liver and prevents LDL-C from oxidative modification [20].

\section{Paraoxonase Gene Cluster}

It comprises PON1, PON2, and PON3 genes positioned on chromosome $7(\mathrm{q} 21,22)$ in humans and on 6 in mouse between q22.3 and q23.1 [21], approximately 27-28 kb [22,23]. These genes may have derived from the common precursor and share structural homology and 70\% nucleotide identity [22]. An extra nucleotide residue in exon 4 of PON1 codes for 105th amino acid but is absent in PON2 and $P O N 3$ which makes it unique in function. A gene coding for one of the pyruvate dehydrogenase kinases $(P D K)[21,24]$ is located next to the PON cluster, and is sufficient to link the PON1 genotypes with diabetic glycemic control in several studies [14].

\section{Evolution of PON Genes}

The evolutionary origins and substrate specificities of PONs is poorly understood. Experiments in the early 1990s, used bacterial systems using Escherichia coli $[25,26]$, yeast using the Pichia pastoris expression system [27], and in insect cells using Baculovirus assemblies [28] to express and purify PON1,PON2 and PON3 proteins and Zhu et al. in 2006 used silk worms for the same purpose [29]. A large body of literature presents traces of PONs from primitive prokaryotes to present day evolved human race. The PON3 gene is conserved in mammals, chimpanzees, Rhesus monkeys, dogs, cows, mice, rats, Caenorhabditis elegans, and higher vertebrates. Only one Paraoxonase gene is present in birds, frogs, and fish, having the highest percentage identity with PON2. However, its homologues are known in the worm C. elegans, plants, bacteria, and fungi $[15,22]$. Bacterial systems do have a presence of $P O N$ genes. However, not all bacteria carry PON genes, the exception is mostly Gram negative ones in which acyl homoserine lactones (AHLs)as quorum sensing signal molecules are abundant e.g., Pseudomonas aeroginosa, Vibrio fisheri, etc. [30-33]. To these AHLs, mammalian PONs act as quorum quenching and degrade the biofilms created by bacteria. PON like genes, namely "Partner of Numb", 672 amino acid long, 72KDa in other model organisms like Drosophila melanogaster (representing insects) play a role in embryonic tube development and asymmetric neuroblast division and its predominant expression is reserved in embryos [34]. In addition, in higher vertebrates (birds, amphibia, reptiles) PON like genes are present but no PON genes have been identified in viruses till date. In the case of protozoa and primitive metazoan, the PONs are likely to relate to innate immunity rather than diverging to detoxification functions which could have been the result of a gene duplication event [35]. Such genes do also exist in the genomes of extinct human subspecies (Homo neanderthalensis, 
Homo sapiens denisovan) and other primates when insilico search tools for comparison with the human situation were done on the NCBI database for PONs (using key terms PON3, Homo sapiens). For a more detailed analysis of the distribution of paraoxonase genes in the three kingdoms of terrestrial life extensive literature has yet to be evaluated to discuss the detailed origin and function of each of these enzymes. A total of 114 organisms have orthologs with human PON genes, sequences of which are available on NCBI database.

Interestingly, the first organophosphate-degrading bacterial species, Flavobacterium sp. ATCC27551 possessed an opd gene that showed transposon-like architecture, with widespread distribution of the gene among other microbial species which hydrolyze organophosphates(OPs) containing the opd (harboured by fungi, cyanobacteria, E. coli ( $y h f V$ ) andMycobacterium tuberculosis) which might have occurred through lateral DNA transfer [36,37]. These hidden facts connect evolution of PON enzymes from primitive prokaryotes to a higher order of hierarchy in mammals and then to humans. According to phylogenetic analysis, PON2 is the eldest and PON1 is the newest of the PON family [15]. PON1 and PON3 reside in the cholesterol-carrying particle HDL, whereas PON2 is found in tissues [16] and all are calcium dependent $[25,38]$. Unlike human PON1 and PON3, PON2 is intracellular being coupled with membrane fractions $[19,22]$, found in the endothelial cells, smooth muscle cells, and macrophages of the arterial wall and is absent in HDL, LDL, or the media of cultured cells [22].

\section{Paraoxonase 3 (PON3) 3.1.1.2}

Credentials to human PON3 gene identification were documented first from the genome data base (GDB) by Primo-Parmo et al. [22] in 1996. It was similar but not identical to PON1. Ozols (1999) purified the same protein [39] from rabbit liver microsomes. After sequencing, it showed $60 \%$ identity with rabbit serum PON1 and $84 \%$ similarity with the PON3sequence as given by Primo-Parma et al., covering 350 residues with non-glycosylated hydrophobic amino terminus. Likewise, Draganov et al. [14] were the first topurify and characterize a mammalian (rabbit) plasma PON3. They also expressed the rabbit PON3 cDNA in 293T/17 cells and found the same specificity (to hydrolyze lactones and not OPs, a necessary step for its purification) and the same molecular mass of the cloned enzyme as that of the rabbit serum purified one. Later on, Rodrigo and his team worked on purification and characterization of rat liver microsomal PON3 [40] protein. It was 95\% identical with the deduced cDNA sequence of the mouse PON3, 67\% identical to rat PON1, and with similar homology between PON1's and PON3's of other species. Brushia et al. [28] then expressed and purified PON1Q192 from baculovirus assemblies. Subsequently, Draganov et al. [41] purified all the three human PONs from the same expression systems. Then expression of active human PON3 protein appeared as inclusion bodies in E. coli by Lu et al. [25]. It was soluble with high levels of Triton X-100.

PON3 is sited between PON1 and PON2 and is the least studied compared to other PON homologues. In both human and mouse all three PONs contain nine exons of approximately the same length, eight introns, and TATA-less promoters [22]. PON1 has 355 amino acid residues whereas PON2 and PON3 have 354 amino acids. At codon position 106, lysine in human PON2 and PON3 is missing [22,42]. All the amino acids required for PON3 activity are conserved between the human, rabbit, and mouse sequences $[40,43]$. These residues are also preserved in PON1 and PON2. The conserved histidine at position 243 and tryptophan at position 281 in both PON1 and PON2 are replaced by lysine and leucine respectively in PON3 of both human and murine sequences [44].

\section{PON3: Single Nucleotides Variants (SNPs) and Haplotypes}

Studies in the 1960s and 1970s demonstrated polymorphic distribution of PON1 activity and frequency of respective phenotypes among populations of different ethnic groups [45]. The PON2 and PON3 knowledge was extremely limited in the late 1990s, although few emerging studies reported genetic associations with metabolic diseases [46,47]. The SNPs of paraoxonases, mainly PON1, were reported in literature later on, especially their significant role in CAD causation. Furthermore, experimental findings quoted antioxidant behavior of PON2 and PON3 but were silent regarding 
involvement of their respective SNPs. Presently, information about PON3 genotypes and its SNPs is scarce $[48,49]$ and the influence of such substitutions or deletions is unknown in various intermediary pathways where enzyme levels are of clinical significance. A prospective Northwick Park Heart study by Robertson et al. in 2003 reported twoSNPs of hPON3 genes at positions 99 alanine (GCG) to alanine (GCA) and at 107aspartic acid (GAC) to asparagine (AAC). However, these SNPs have not revealed much information about its association with CAD [50].

Whereas, Campo et al., when compared their data to PON1 and PON2, no polymorphism could be identified for PON3. However, serine to threonine substitution around position 311 and glycine to aspartic acid at 324 position were detected in a southern Italy population [48]. The functional consequences, however, of these polymorphisms regarding CAD development is not clear. The first coverage report governing the alliance of the PON3 gene with serum PON1 activity in systemic lupus erythematosus (SLE) and atherosclerosis risk, did not reveal any significant association with PON3 variants [51]. Interestingly, two SNPs had significant influence on PON1(phenyacetate) activity, out of total six studied variants and accounted for $3 \%$ of variation in the PON1 activity, emphasizing neglected variants to be identified. In spite of PON3 promoter gene sequencing or numerous case-control studies aiming to determine ability of the variants to protect LDL from oxidation, rarely any of the variants had demonstrated an influence over gene expression to date except in one or two studies [50,52], with no conclusive results about PON3 association with CAD risk as summarized in the Table 1.

Often, these might have included inappropriate sample size, population heterogeneity, and/or used different genotyping approaches that are difficult to interpret. Although, huge inter-individual variation in PON3 activity/concentration has probably contributed to some extend defense against CAD. Notably, Wang et al. detected -133 C >A polymorphism in the PON3 gene [53] which was located at a potential binding site for transcription factor LFA-1(Integrin Lymphocyte Function- associated Antigen) but no report to date is available regarding role of LFA-1 in PON3 activity and expression regulation, although $\mathrm{LF}-\mathrm{Al}$ has its interaction (binding sites) with the promoter regions of several liver-specific genes like $A P O A 1, A P O B 1, A P O A 4$, and pyruvate kinase [54]. LFA-1, a receptor for intercellular adhesion molecules (ICAMs), consists of integrin alpha $\mathrm{L}$ chain which combines with the beta-2 chain to form it. LFA-1 plays a key role in leukocyte intercellular adhesion through interaction with ICAMs, like HDL [55-57]. PON3 association with HDL and involvement in immune response [58] may pave the road to investigate a further role of immune regulation of HDL, and, specifically, PON3 activity attributed by its respective SNPs. PON3 promoter characterization becomes necessary for understanding its gene regulation so as to elucidate its role in treatment.

Aragones et al. [52] demonstrated six functionally active promoter polymorphisms of the PON3 (-567 C/T, -665 A/G, -746 C/T, -4105 G/A, -4970 T/G, -4984 A/G), with significantly moderate influence on PON3 circulating levels. Typically, the least frequent genotype showed $10 \%$ reduction in serum PON3 levels, compared to most frequent genotype indicating strong association and confirmed TGTAGG, TGTGTA, CACGTA being the most frequent haplotypes influencing serum PON3 concentration when adjusted for gender, age, and body mass index [56]. Another investigation in our laboratory also could not detect previously reported two SNPs (i.e., D107N and G324D) in our population groups, however, the polymorphism in coding region at A99A resulted in significantly low PON3 activity and low PON3 circulatory concentration in these individuals who harbored the A99Aheterozygous mutant in particular [59] (full text not published, for more details see Table 1). Therefore, current findings strongly emphasize the need to explore more information on PON3 to get a better understanding of CAD as well as particular genotypes associated with it. As there is a paucity of studies on PON3 polymorphisms amongst various population groups at present, it is worthwhile to undertake polymorphisms into account in a homogeneous population to find the genetic basis of disease. Besides these, it is also not known which alleles in the PON3 have greater activity for its natural substrate in vivo. 


\section{Substrate Specificities and PON3 Status}

All three PONs metabolize derivatives of arachidonic acid (5-hydroxy cicosatetraeomic acid 1,5 lactone and 4-hydroxy docosahexaenoic acid) whereas PON3 is exclusive to lactones hydrolysis such as lipid-lowering statin pro-drugs lovastatin and simvastatin [60] and the diuretic spironolactone, canrenone, hence exhibits lactonase activity. Organophosphates are exclusively hydrolyzed by PON1 whereas PON3 possesses the most limited arylesterase activity and is devoid of organophosphatase activity against the synthetic substrates like paraoxon and phenylacetate [14]. Aceylhomoserine lactones are hydrolyzed by paraoxonases, and are now accepted as chief quorum sensing indicators in bacterial virulence, and modulators of host anti-inflammatory response [30,32]. To answer, how PON3 imparts anti-atherogenic activity and its endogenous substrates remains largely unknown despite its usual task as paraoxonase/arylesterase. Moreover, laboratory evolution [31] and structural activity studies on PON1 [61] indicate that PON1 was the first detected lactonase among PON members [62]. Now lactonase activity is the characteristic feature of all PONs. All PONs have similar active site residues resembling one another, but PON1 variants have evolved with different activity patterns [31,63] with due course of evolution. Thus, derived lactones from fatty acid oxidation may constitute the native substrates of PON1 [41,64].

Fatty acid esters, fatty acid ethers whether exogenous or endogenous (such as Arylesters, HTL) and cyclic carbonates are only hydrolyzed by PONs $[31,42,61]$ whereas peptides, oligonucleotides, oligosaccharides, or epoxides are not hydrolyzed by Paraoxonase isoforms. Following the discovery of PON2 and PON3, these were also termed paraoxonases although neither one hydrolyzed Paraoxon [22]. After discussions on the appropriate nomenclature for the PONs, naming of the three PONs should be delayed until the natural physiological substrates are identified [42] which remains an open question to date and searching for its alternative substrates and catalytic activity in different species across prokaryotic bacteria to mammalian cells is in progress to achieve alternative functions harbored by these three enzymes. Previous structure-activity relationship studies demonstrate that PONs have a high specificity for lipophilic lactones, suggesting that such compounds may be representative of native substrates. This report describes the ability of PONs to hydrolyze two bioactive d-lactones derived from arachidonic acid, 5,6-dihydroxy-eicosatrienoic acid lactone (5,6-DHTL), and cyclo-epoxycyclopentenone (cyclo-EC). Both lactones were very efficiently hydrolyzed by purified PON3. PON1 efficiently hydrolyzed 5,6-DHTL, but with a specific activity about 15-fold lower than PON3. Studies with the PON inhibitor EDTA and a serine esterase inhibitor indicated that the PONs are the main contributors to hydrolysis of the lactones in human and mouse liver homogenates [65].

\section{Amino Acid Sequence Similarity}

When the amino acid sequences of the known paraoxonase isoforms are compared with other known hydrolyzing enzymes, hardly any structural similarities do occur. Comparison of serum acetyl hydrolase (PAF-AH) and paraoxonase 1 (PON1) has been already evaluated by ErdalBenli et al. [66]. Additionally, Russell L. Carr et al. [67], found species differences in paraoxonase mediated hydrolysis of severalorganophosphorus insecticide metabolites. These differences are possibly due to effects on either posttranslational modification of the catalytic structure of PON1 or the induction of other factors that play roles in the activity of PON1.

Bacterial phosphotriesterases (PTEs), amidohydrolase superfamily, differ from the eukaryotic organophosphatases; PTEs are $(\beta / \alpha)_{8}$ barrels with an active site containing two transition metal ions such as $\mathrm{Co}^{2+}, \mathrm{Mn}^{2+}$, or $\mathrm{Zn}^{2+}$. PTE from Pseudomonas diminuta hydrolyzes paraoxon, Dihydro-caumarin(DHC), and other lactones whereas bacterial lactonases, dubbed PTE-like lactonases (or PLL), have been identified to possess both lactonase and organophosphatase activities [38]. Lactones are natural compounds, many of them with high biological activity, while organophosphates are human-made chemicals introduced in the 20th century [38]. Thus, it is plausible that lactonase is the primary activity for which the enzymes discussed here evolved for, while the organophosphatase activity arose as a promiscuous activity during their evolution. 


\section{Paraoxonase3 Structure: (PDB 1v04)}

The crystal structure of serum paraoxonase 1 has been deduced [31,32,38,61-63]. However, research on more catalytic functions focusing PON3 is not yet evaluated. Many functions of this enzyme and why differences in PON3 and PON1 occur are still not clear. All PONs utilize a catalytic calcium ion, which functions as an oxy-anionto stabilize substrate and reaction states. Additionally, this enzyme active site employs two histidine residues (His115 and 134) involved in proton transfers, a glutamic acid(Glu53) to stabilize reactive hydrogens, and an asparagine(Asn168) to stabilize transition states and intermediates in the active site $[31,38,62,63,68]$. The exact mechanism is still a subject of further research and it is suggested that the His 115 residue is not necessary for the lactonase and arylesterase activity of the enzyme [69].

The enzyme status of PON3 which encompasses its activity and circulatory concentration needs to be quantified as it essentially upholds the predetermined task in disease development or progression [70]. Despite similarity in residues, the active site of PON3 is larger than that of PON2 and PON1. Thus, it has greater ability to hold bulky statin lactones and spironolactone, whereas PON1 is capable of hydrolyzing only non-substituted and short chain-substituted lactones [38]. The physiological substrates of PON3 are still not known and are under investigation, which may better help to determine functional aspects of PON3 as a therapeutic candidate. There is no direct measurement for PON3 activity as information about its exact physiological substrates are uncertain and statinase activity is exclusively known to it [60]. Various researchers have performed DHC based [14,40,71] and statin based estimation [60] to indirectly correlate PON3 activity from serum and have reported its lower levels in obese as compared to slim school children [60] keeping in mind its more specific and exclusive substrates. This sheds light on new avenues in diagnosis, especially as an early indicator of susceptibility to arteriosclerosis as well as an indicator of potential drug side effects.

\section{PON3 Concentration}

The efficiency of PON3 to prevent copper-induced LDL oxidation is 100 times more than PON1 but is found about 200 times less abundantly than PON1 in rabbit HDL [14]. In mice, PON levels are negatively correlated with atherosclerosis [72-74]. Indeed, PON3 is atheroprotective, but a dearth of reliable methods to estimate its concentration in the serum is one of the hurdle which prevents its use for therapeutic benefit. Aragones et al. [52] developed enzyme-linked immunosorbent assay (ELISA) to measure serum PON3 concentration in a population-based study. They found its concentration decreases with growing old. However, no significant association could be drawn with sex, body mass index, or smoking status [52]. Thus, PON3 serum concentration and activity are to be predetermined when carrying out association studies. Therefore, PONs give atheroprotection by two means, firstly, by exerting their effect on HDL particles(PON1 and PON3) and secondly being friendly, intracellular PON2 protects macrophages and possibly other cells of arterial wall [75].

\section{Histological Distribution}

PON3 is produced primarily in the liver and released into the blood circulation, where it gets bound to HDL and apolipoprotein A1. IHC (Immuno-histological-chemistry) sections from different tissues show its variable distribution in body, whereas PON3 gene expression is chiefly observed in the liver and kidney [76]. The defensive nature of PON3 probably goes beyond circulation, since it is markedly distributed to various tissues including the lung, liver, pancreas and intestine, and eye [77]. Thus, immuno-histochemical localization can provide a better platform to investigate the changes in the distribution of these enzymes in a variety of diseases, stage specific changes in cell-subtypes, and it can be correlated with various pathways involved in pathological condition if its subcellular localization becomes clearer. 


\section{Antioxidant Potential}

Liver is the primary site of lipid metabolism [78]. Ox-LDL increases the generation of oxidative stress by increasing the production of intracellular ROS and lipid peroxidation products [10]. PON3 reduces early oxidative products and thereby suppresses the propagation of oxidation by hydrolyzing biologically active oxidized phospholipids and lipid hydroperoxides in oxidized LDL respectively $[19,79]$.

Varied cellular (macrophages and Hepatoma cells) and experimental rodent systems (high fat diet mice, apo $E^{-/}$mice) illustrate oxidative stress has different influences on PON protein expression. Oxidative stress downregulates PON1, upregulates PON2, and unalters PON3 expression $[80,81]$. Evidently, cell culture study on mouse peritoneal macrophages (MPMs) from control and apo $E^{-/}$ (rich in lipid peroxides) mice, incubated under an oxidizing environment (in the presence of oxidized phospholipids and supplied with high fat atherogenic diet) showed PON2 mRNA expression and $50 \%$ elevated lactonase activity towards dihydro-coumarin, but unaffected PON3 mRNA expression. Further, incubation with purified PON2 and PON3 demonstrated low cellular lipid peroxide content [82] in $a p o E^{-/-}$macrophages. This evidence needs more evaluation to draw out the exact relationship between macrophage oxidative stress, paraoxonase proteins, and atherosclerosis.

Dragnov et al. have reported the efficiency of purified rabbit PON3 in protecting LDL-C against oxidation is 100 times more than rabbit PON1 [83], besides its capability of preventing copper induced LDL-C oxidation in vitro [14]. Reddy et al. have shown that LDL-C when incubated with stably transfected cells over-expressing human PON3, have significantly less lipid hydroxides and poor monocyte chemotactic activity [80]. In addition to these, PON3 has been linked to oxidative stress for the first time in the context of modulating the levels of reactive oxygen species (ROS) in ex vivo and in in vivo experimental models [84,85]. In association with Q10, it protects against mitochondrial oxidative stress [85]. Thus, it is important to carry out linkage studies in individuals of different genetic make-up with diverse ethnicities to discover its anti-atherogenic circuitry influencing the lipoprotein metabolism and mediating its role in mitochondrial function as well.

\section{PON3 Regulation in Various Diseases}

Regarding aforementioned antioxidant functions of $P O N 3$, it is difficult to state its regulation by inflammation and oxidative stress in atherosclerosis in the absence of its known physiological substrates. PON3 appears to be influenced by oxidative stress. However, a few reports on knockout mice models suggest PON3 expression remains unchanged in response to oxidative stress. Shamir et al. reported Caco-2 cells subjected to Fe/Asc-induced oxidative stress showed no change in PON3 expression profile at gene and protein level with little reduction in statinase activity [86]. In a similar manner, apo $E^{-/-}$ MPMs, under stress conditions showed no significant change in PON3 mRNA levels even in the absence of statinase activity, but pomegranate juice/vitamin E supplementation augmented statinase activity in apo $E^{-/-}$mice, indicating its regulation by oxidative stress [71,86-88]. In contrast, J774 A.1 murine macrophages-like cells showed reduced PON3 lovastatinase activity when pomegranate juice was given to these cells [89]. Pro-oxidative environment however reduced PON3 activity in MPM isolates from C57BL/6 mice without having any impact on gene expression [81]. Furthermore, PON3 directed hepatic expression in murine model C57Bl6/J was not affected by genetic background or $\operatorname{diet}[90]$.

Further, its upregulated expression was reported in late gestation in fetal rat, sheep, and humans, which may prove it as an anti-oxidative entity in premature or newborn babies [91]. Additionally, obtained colonic samples from healthy individuals, patients of Crohn's disease and ulcerative colitis by Boehm et al. [92] detected its mRNA in 1/14 cases with active ulcerative colitis and in 3/17 Crohn's disease patients, compared to 10/25 controls [70], suggesting that inflammation and oxidative stress in inflammatory bowel disease patients may have downregulated intestinal PON3 expression which is similar to the results reported earlier in systemic/local inflammatory disoders e.g., ulcerative colitis, diabetic neuropathy and retinopathy, rheumatoid arthritis and glomerulonephritis, where 
serum Paraoxonase (PON1) levels and activity were found to be reduced $[84,93,94]$. On the contrary, its upregulated profile in a variety of tumor samples or in cell lines has also been documented [85]. Overall, these observations suggest the role of PON3 in atheroprotection via oxidative modification of lipids and in initiation of inflammatory events [95].

In support of this, Tward and Rozenberg et al. propose PONs involvement in vascular disease as its knock-out counterpart had shown increased susceptibility to atherosclerosis $[96,97]$ and developed $42 \%$ excess in stenosis [98]. Similarly, the development of human PON3 transgenic mice by Shih et al. [72], instruct better comprehension of atheroprotective actions of PON3, 4-7-fold more PON3 expression in their liver, and presented reduced lesions comparable to control ones when given an atherogenic diet. Availability of knockout mice models for the different paraoxonase isoforms has now made it easier to understand more biological functions of PON3 in different diseases. This has been facilitated by D.M. Shih and co-workers [99]. Notably, reduction in adiposity, atherosclerotic lesions, and monocyte chemoattractant protein-1-(MCP-1) in control and LDL receptor Knock Out (KO) mice overexpressing $h P O N 3$ also suggests synergy of $P O N 3$ in obesity control and atherosclerosis [72]. In the past, cholesterol transcriptional regulator, Sterol regulatory element binding protein-(SREBP-2),-104to -95bp triggered activity of $P O N 1$ promoter in a dose-specific manner signified an extra lipid-associated mechanism of PON1 activation [98]. These findings may pave our way of understanding a mechanistic approach towards another homolog of the PON family i.e., PON3 and its role in prevention of coronary artery disease. Unfortunately, no report to date has accounted for LFA-1 transcription factor in PON3 gene regulation despite LFA-1 interaction with the promoter regions of several liver-specific genes [54]. Wang et al. detected $-133 \mathrm{C}>\mathrm{A}$ polymorphism in the PON3 [53] which was located at a potential binding site for LFA-1. Our team also made an attempt to study the functional consequence of this -133 C $>$ A polymorphism in North West Punjabi Indians and we could only detect the polymorphic site but no significant association with CAD (Table 1). In view of poor understanding of PON3 with conflicting results, additional studies explaining its promoter interaction with the transcription factors can elucidate its regulation.

\section{PON3 Gene Expression}

For further characterization of Human PON3 activity against atherosclerosis, gene expression studies have been performed which revealed human PON3 appears in widely distributed tissues [77]. However, its mRNA expression is precisely found in the liver and kidneys [76] and has been already discovered in murine macrophages with specific statinase activity [81]. Likewise, another genetically modified animal model over expressing $h P O N 3$ with $a p o E^{-/-}$KO background showed poor susceptibility of LDL to oxidation, as HDL had efficient efflux cholesterol from macrophages [90]. This study also established that mice HDL particles do not house PON3. Similarly, with administration of adenovirus expressing $h P O N 3$, reduced arterial lesion size was observed with no anti-inflammatory/antioxidative effects $[90,100]$. However, the anti-inflammatory potential was shown by a carbon-tetrachloride $\left(\mathrm{CCl}_{4}\right)$ induced liver injury murine model over expressing PON3 which led to increased glutathione levels whereas decreased malonyl-di-aldehyde (MDA) levels, tumor necrosis factor (TNF- $\alpha$ ), and interleukin-(IL-1 $\beta)$, respectively [101,102]. Overall, these studies sustain PON3 against atherosclerosis and antioxidant synergistically to be explored for future therapeutics besides its anti-inflammatory function.

\section{Role of Environmental Factors}

Risk factors associated with CAD are age, nutrition, lifestyle, smoking status, and alcohol consumption. PON3 activity decreases with age [52]. In elderly patients, there is an increased susceptibility of HDL to oxidation. Recent experimental findings have proven PON3 involvement not only with CVDs, but with obesity also [72]. In general, sedentary lifestyle is equally associated with greater risk of $\mathrm{CHD}$, stroke, hypertension, hypercholesterolemia, whereas regular physical activity improves quality of life and guards against the incidence and progression of CHD [103,104]. Effects of 
moderate aerobic training performed on a rat model by Rita et al. [89] confirmed first the upregulation of PON3 mRNA, protein levels, and enzymatic activity, rather than PON1. Feasibility of knockout mice models for the different paraoxonase isoforms has made investigation of such animals easier, for understanding of more biological functions in different diseases also. These credentials have been supplemented by a group led by Shih et al. (2015) [99]. Transgenic male mice over-expressing hPON3 generated by Shih et al. [72] also demonstrated elevated expression of PON3 bestowed protection against obesity and atherosclerosis in these mice. These parallel results emphasize PON3 as an attractive candidate for future studies in relation to its joint participation in CVD and obesity. Thus, sustained physical activity awards beneficial effects on lipoprotein metabolism, by decreasing plasma triglyceride and increasing HDL-cholesterol levels, which bears antioxidant properties and cardioprotection.

For centuries, one of the generally accepted notionss is that consuming fruits and vegetables and wine is beneficial for protection against heart disease. Polyphenolic compounds such as flavonoids quercetin and myricetin in these foods are responsible for their atheroprotective effect [105-107] and inhibit LDL oxidation in humans as well as in animal models [107,108]. On the other hand, tobacco use is strongly related to CAD. Smoking cigarettes or beedi is associated with increase in the risk of myocardial infarction [109]. Red wine is a rich dietary source for polyphenols. The phytoalexin in resveratrol [108] actively contributes to the beneficial effects of wine and also modulates PON1 expression [110]. Pharmacologically, significant micromolar units of resveratrol accumulation in liver [93] and in plasma have been reported after moderate wine intake. Therefore, pharmacological modulation of PON3 activity/gene expression might lead to a better therapeutic weapon against CAD and merits further research.

\section{Summary and Conclusions}

The present review is an attempt to discuss the role of PON3 enzyme in CAD etio-pathogenesis beyond the thought of conventional Paraoxonases like PON1 (OP-hydrolyzing enzymes) which flock against cholinergic crisis. Paraoxonases act as crucial endogenous enzymes against oxidative stress which have been implicated in the pathogenesis of cardiovascular diseases. Emerging evidence supports the role of PON1 and PON3 (HDL associated enzyme) in prevention of atherosclerosis. It inhibits peroxidation ofLDL-C and inactivates LDL-derived oxidized phospholipids [14], thereby reducing its oxidized levels that are involved in initiation of atherosclerosis [10]. In vitro analysis of the recombinant HDL (rHDL) suggests that PON3 interacts with apoA1-HDL particles in a manner similar to that of PON1 $[47,58]$. This interface follows specific, inducible changes in the enzyme's active site and increases stability of both rPON3- apoA1-HDL (half-life) in the presence of calcium chelating agent by $>45$-fold. Being antiatherogenic, rPON3 also stimulates the HDL-mediated cholesterol efflux from macrophages [47]. Its overexpression prevents atherogenesis in murine models $[72,97,111]$. However, in clinical settings, patients who represent fully established plaques, need care as it is too late for prophylactic approaches. Possibly all the three PON proteins play an important role in a number of inflammatory disorders. However, their exact mechanisms of action are not clear and need to be determined [112]. PON3, therefore, may be a potential preventive agent against atherosclerosis development provided identification of its lead substances, increasing or decreasing its endogenous levels [113] despite several explorations undertaken at gene/protein levels [48,50,52,114,115]. Downstream targets, epigenetic modifications, and regulatory microRNAs (miRNAs) can also be explored to identify the potential targets of PON3 in addition to dietary interventions by polyphenols (Figure 1). Once regulatory circuits of PON3 are deciphered, it would be easier to understand and translate these esterases for therapeutic benefit. 
Table 1. Tabulated representation of studies, worldwide, deciphering PON3 variants and investigating the role in coronary artery disease.

\begin{tabular}{|c|c|c|c|c|}
\hline Study & Subjects Enrolled & $\begin{array}{l}\text { PON3 SNPs } \\
\text { Studied }\end{array}$ & Outcome & Author, Year \\
\hline $\begin{array}{c}\text { Prospective } \\
\text { Northwick Park } \\
\text { Heart study II; to } \\
\text { evaluate the effect } \\
\text { of SNPs on CHD } \\
\text { risk }\end{array}$ & 3052 healthy men & $\begin{array}{l}\text { A99A (GCG to } \\
\text { GCA) } \\
\text { D107N (GAC) to } \\
\text { (AAC) }\end{array}$ & $\begin{array}{l}\text { A99A SNP, did not revealed much } \\
\text { information about its association } \\
\text { with CAD but D107N was absent } \\
\text { in the population. }\end{array}$ & $\begin{array}{l}\text { Robertson et al. [50] } \\
\qquad(2003)\end{array}$ \\
\hline $\begin{array}{l}\text { Polymorphisms } \\
\text { screening of } P O N \\
\text { cluster in a Chinese } \\
\text { Han population }\end{array}$ & $\begin{array}{l}949 \text { subjects in the } \\
474 \text { cases, } 475 \\
\text { controls }\end{array}$ & $-133 \mathrm{C}>\mathrm{A}$ & $\begin{array}{l}\text { Not found significant effect on } \\
\text { CHD risk but detected }-133 \mathrm{C}>\mathrm{A} \\
\mathrm{SNP} \text { in } P O N 3 \text { located at a potential } \\
\text { binding site for transcription factor } \\
\text { LFA-1(Integrin Lymphocyte } \\
\text { Function-associated Antigen) }\end{array}$ & Wang et al. [53] (2003) \\
\hline $\begin{array}{l}\text { Identification of } \\
\text { PON3 mutations in } \\
\text { a population of } \\
\text { Southern Italy }\end{array}$ & 1143 blood donors & $\begin{array}{l}\text { G51G } \\
\text { G73G } \\
\text { A99A } \\
\text { S311T } \\
\text { G324D }\end{array}$ & $\begin{array}{l}\text { G51G, G73G, A99A were silent and } \\
\text { S311T, G324D were missense } \\
\text { mutations with no clarity on } \\
\text { function in CAD development }\end{array}$ & Campo et al. [48] (2004) \\
\hline $\begin{array}{l}\text { PON gene cluster } \\
\text { TagSNPs } \\
\text { analysis-on } \\
\text { illumina platform }\end{array}$ & $\begin{array}{l}500 \text { Caucasian } \\
\text { males }\end{array}$ & $\begin{array}{c}\text { PON1, PON2 and } \\
\text { PON3 }\end{array}$ & $\begin{array}{l}\text { No significant association with } \\
\text { CAD disease }\end{array}$ & Carlson et al. [114] (2006) \\
\hline $\begin{array}{l}\text { Association study; } \\
\text { PON3 with serum } \\
\text { PON1 activity, risk } \\
\text { of atherosclerosis } \\
\text { in SLE cases }\end{array}$ & $\begin{array}{l}377 \text { cases and } 482 \\
\text { controls (US whites } \\
\text { and blacks) }\end{array}$ & $\begin{array}{c}\text { PON3 } \\
\text { (A10340C, A2115T), } \\
\text { PON1 } \\
\text { (L55M, Q192R) }\end{array}$ & $\begin{array}{l}\text { All four SNPs explained } 2 \%, 1 \% \text {, } \\
8 \% \text {, and } 19 \% \text { of the variation in } \\
\text { PON1 activity, respectively. } \\
\text { PON3 SNPs described only } 3 \% \text { of } \\
\text { variation in PON1 activity }\end{array}$ & Sanghera et al. [51] (2008) \\
\hline $\begin{array}{l}\text { Influence of genetic } \\
\text { polymorphisms of } \\
P O N \text { on lactonase } \\
\text { activity }\end{array}$ & Healthy population & $\begin{array}{l}\text { PON3-567, } \\
\text { PON3-665, } \\
\text { PON3-746, } \\
\text { PON3-4105, } \\
\text { PON3-4970, } \\
\text { PON3-4984 }\end{array}$ & $\begin{array}{l}\text { Lactonase activity was lower than } \\
\text { Paraoxonase activity which } \\
\text { indicated evaluation of liver } \\
\text { function in clinics }\end{array}$ & $\begin{array}{l}\text { Marsillach et al. [115] } \\
\text { (2009) }\end{array}$ \\
\hline $\begin{array}{c}\text { PON3; } \\
\text { concentration } \\
\text { determination and } \\
\text { its association } \\
\text { analysis with } \\
\text { promoter } \\
\text { polymorphisms }\end{array}$ & $\begin{array}{l}\quad n=356 ; 156 \\
\text { women, } 200 \text { men; } \\
\text { mean age: } 47 \text { years, } \\
\text { of Caucasian from } \\
\text { the Mediterranean } \\
\text { region of Catalonia }\end{array}$ & $\begin{array}{c}(-567 \mathrm{C} / \mathrm{T},-665 \mathrm{~A} / \mathrm{G}, \\
-746 \mathrm{C} / \mathrm{T},-4105 \mathrm{G} / \mathrm{A}, \\
-4970 \mathrm{~T} / \mathrm{G},-4984 \\
\mathrm{~A} / \mathrm{G})\end{array}$ & $\begin{array}{l}\text { Promoter SNPs associated with } \\
\text { PON3 serum concentration. } \\
\text { TGTAGG, TGTGTA, CACGTA } \\
\text { haplotypes were significantly } \\
\text { associated with changes in serum } \\
\text { PON3 concentration when adjusted } \\
\text { for gender, age, BMI }\end{array}$ & $\begin{array}{l}\text { Aragones et al. [52] } \\
\qquad(2011)\end{array}$ \\
\hline $\begin{array}{l}\text { PON1 and PON3; } \\
\text { atorvastatin } \\
\text { hydrolysis }\end{array}$ & $\begin{array}{l}\text { Blood and liver } \\
\text { tissues of patients } \\
\text { undergoing } \\
\text { surgery }(n=150)\end{array}$ & $\begin{array}{c}-4984 \mathrm{~A} / \mathrm{G} \\
-4105 \mathrm{G} / \mathrm{A} \\
-1091 \mathrm{~A} / \mathrm{G} \\
-746 \mathrm{C} / \mathrm{T} \text { and } \mathrm{F} 21 \mathrm{~F}\end{array}$ & $\begin{array}{l}40 \text { SNPs identified within the } \\
\text { PON-locus associated with changes } \\
\text { in atorvastatin } \delta \text {-lactone hydrolysis } \\
\text { and expression of PON1 but not } \\
\text { PON3. Non genetic factors only } \\
\text { were associated with PON3 } \\
\text { expression }\end{array}$ & $\begin{array}{l}\text { Riedmaier et al. [116] } \\
\text { (2011) }\end{array}$ \\
\hline $\begin{array}{l}\text { Study of } 51 \\
\text { common } \\
\text { polymorphisms in } \\
\text { the PON cluster }\end{array}$ & $\begin{array}{l}1328 \text { Caucasian } \\
\text { males }\end{array}$ & $\begin{array}{l}\text { PON3 (rs17884000, } \\
\text { rs9640632, rs468, } \\
\text { rs11768074 } \\
\text { rs10487132 } \\
\text { rs740264) }\end{array}$ & $\begin{array}{l}\text { Predicted PON1 activity but not } \\
\text { vascular disease }\end{array}$ & $\begin{array}{l}\text { Daniel S. Kim et al. [117] } \\
\text { (2012) }\end{array}$ \\
\hline $\begin{array}{l}\text { Case control study } \\
\text { in North West } \\
\text { Indian Punjabis }\end{array}$ & $\begin{array}{l}n=300 \text { cases, } n= \\
300 \text { proven CAD } \\
\text { patients }\end{array}$ & $\begin{array}{l}\text { C-133A, A99A, } \\
\text { D107N, G324D }\end{array}$ & $\begin{array}{l}\text { Low Paraoxonase } 3 \text { activity, } \\
\text { circulatory concentration and A99A } \\
\text { variants were predictive risks for } \\
\text { angiographically proven CAD }\end{array}$ & $\begin{array}{l}\text { K. Priyanka et al. [59] } \\
\text { (2017) }\end{array}$ \\
\hline
\end{tabular}




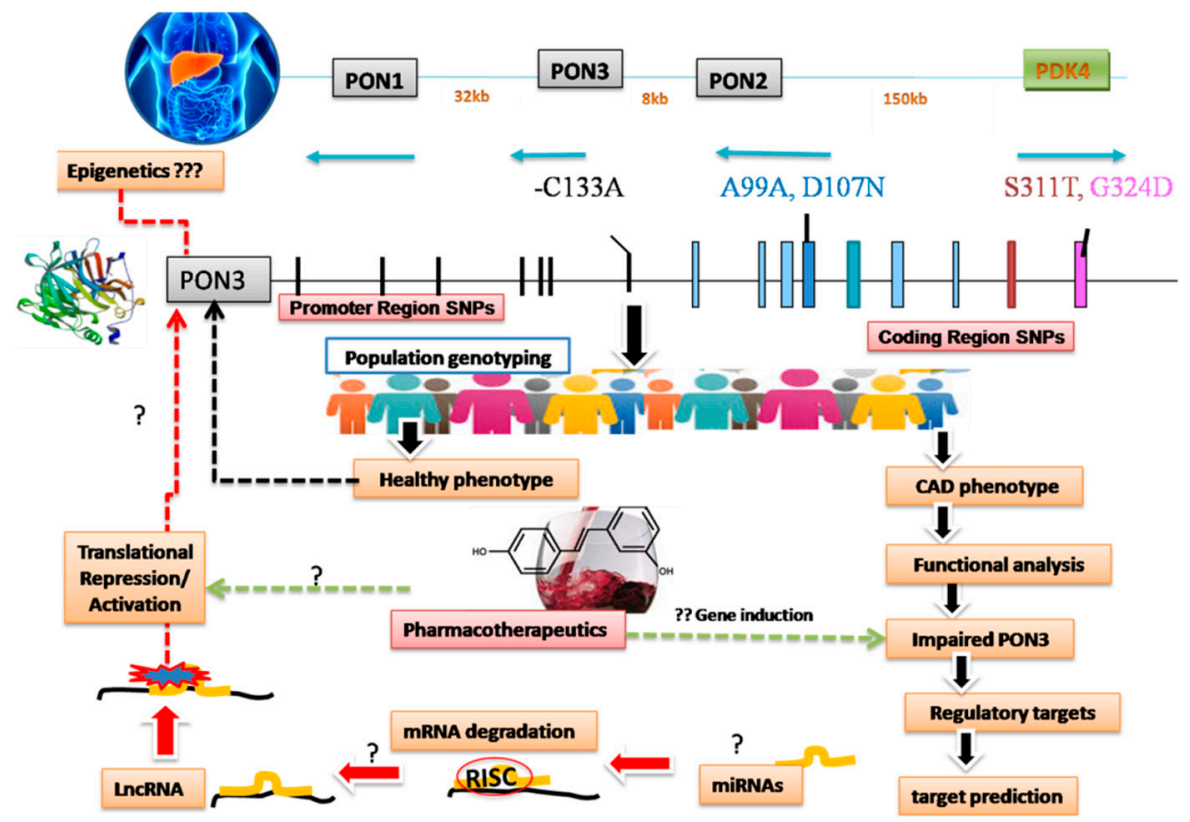

Figure 1. Schematic representation of interconnected hidden links to be explored in pathophysiology of coronary artery disease (CAD) associated with impaired Paraoxonases. sPON3 is synthesized in the liver and associated with high-density lipoprotein (HDL). PON gene cluster on chromosome 7 (q21, 22) comprises PON1, PON2, and PON3 sharing homology with each other. Across the globe, several investigations in population genotyping have found very few polymorphic sites in the PON3 (-133C/A in the promoter region and D107N, S311T, G324D in the coding region) which has a direct role in CAD progression except in one or two studies where serum levels and CAD phenotype have a positive correlation with the disease. Studies intending to report functional characterization of mutated PON3 at regulatory level or epigenetic control could better predict the underlying mechanisms operating at transcriptional/translational levels. For this, miRNA moleculesmight give clues to identify its major targets as i.e., PON3. In this arm regulatory miRNAs and regulation pathways can be deduced in vitro or in vitro to better understand PON3 gene function and regulation so as to exploit the exact inducers of PON3 in translational pharmacotherapeutics.

\section{Future Perspectives}

We are still lacking in paraoxonase research in terms of knowledge regarding understanding its pathobiology and designing therapeutics, despite its pivotal role in several diseases. Rare association studies, and lack of an accurate data regarding its physiological substrates, have limited our understanding of the pathogenesis of the disease. It is still unclear how these PONsdisplay a broad spectrum of activities if instructed/not by a single active site suggesting substrate specificities of these esterases could be under control of different genetic circuitry. There are now available knockout mice models for the different paraoxonase isoforms. It is worth investigating such animals for understanding of more biological functions in different diseases also. Thus, it becomes imperative to discover the potential candidates which modulate Paraoxonase 3 expression and help in improving its status.

Funding: This research received no external funding.

Acknowledgments: Indian Council of Medical Research, New Delhi and Postgraduate Institute of Medical Education and Research, Chandigarh (India).

Conflicts of Interest: The authors declare no conflict of interest.

\section{References}

1. Murray, C.J.; Lopez, A.D. Alternative projections of mortality and disability by cause 1990-2020: Global Burden of Disease Study. Lancet 1997, 349, 1498-1504. [CrossRef] 
2. Kullo, I.J.; Ding, K. Mechanisms of Disease: The genetic basis of coronary heart disease. Nat. Clin. Pract. Neurol. 2007, 4, 558-569. [CrossRef] [PubMed]

3. Enas, E.; Garg, A.; Davidson, M.A.; Nair, V.M.; Huet, B.A.; Yusuf, S. Coronary heart disease and its risk factors in first-generation immigrant Asian Indians to the United States of America. Indian Hear. J. 1996, 48, 3433-3453.

4. Enas, E.A.; Yusuf, S.; Sharma, S. Coronary artery disease in South Asians. Second meeting of the International Working Group, Anaheim, California. Indian Heart J. 1998, 50, 105-113.

5. McKeigue, P.M.; Ferrie, J.E.; Pierpoint, T.; Marmot, M.G.; Marmot, M. Association of early-onset coronary heart disease in South Asian men with glucose intolerance and hyperinsulinemia. Circulation 1993, 87, 152-161. [CrossRef]

6. Janus, E.D.; Postiglione, A.; Singh, R.B.; Lewis, B. The modernization of Asia. Implications for coronary heart disease. Council on Arteriosclerosis of the International Society and Federation of Cardiology. Circulation 1996, 94, 2671-2673. [CrossRef]

7. Ross, R. The Pathogenesis of Atherosclerosis-An Update. N. Engl. J. Med. 1986, 314, 488-500. [CrossRef]

8. Oliver, M. Pioneer research in Britain into atherosclerosis and coronary heart disease-An historical review. Atherosclerosis 2000, 150, 1-12. [CrossRef]

9. Steinberg, D.; Parthasarathy, S.; Carew, T.E.; Khoo, J.C.; Witztum, J.L. Beyond cholesterol. Modifications of low-density lipoprotein that increase its atherogenicity. N. Engl. J. Med. 1989, 320, 915-924.

10. Mahdi, G.; Srikanth, K.; Dmitry, L. Role of Oxidized Lipids in Atherosclerosis, Oxidative Stress and Diseases. In: Dr. Volodymyr Lushchak (Ed.). InTech, 2012. Available online: http://www.intechopen.com/books/ oxidative-stress-and-diseases/role-of-oxidized-lipids-in-atherosclerosis (accessed on 3 October 2019).

11. Wang, Q. Advances in the genetic basis of coronary artery disease. Curr. Atheroscler. Rep. 2005, 7, $235-241$. [CrossRef]

12. Tanne, D.; Yaari, S.; Goldbourt, U. High-density lipoprotein cholesterol and risk of ischemic stroke mortality. A 21-year follow-up of 8586 men from the Israeli Ischemic Heart Disease Study. Stroke 1997, 28, 83-87. [CrossRef] [PubMed]

13. Assmann, G.; Schulte, H.; Von Eckardstein, A.; Huang, Y. High-density lipoprotein cholesterol as a predictor of coronary heart disease risk. The PROCAM experience and pathophysiological implications for reverse cholesterol transport. Atheroscler 1996, 124, 124. [CrossRef]

14. Draganov, D.I.; Stetson, P.L.; Watson, C.E.; Billecke, S.S.; La Du, B.N. Rabbit Serum Paraoxonase 3 (PON3) Is a High-Density Lipoprotein-associated Lactonase and Protects Low Density Lipoprotein against Oxidation. J. Boil. Chem. 2000, 275, 33435-33442. [CrossRef] [PubMed]

15. Watson, A.D.; Berliner, J.A.; Hama, S.Y.; La Du, B.N.; Faull, K.F.; Fogelman, A.M.; Navab, M. Protective effect of high-density lipoprotein associated paraoxonase inhibition of the biological activity of minimally oxidized low density lipoprotein. J. Clin. Investig. 1995, 95, 774-782. [CrossRef]

16. Navab, M.; Van Lenten, B.J.; Reddy, S.T.; Fogelman, A.M. High-density lipoprotein and the dynamics of atherosclerotic lesions. Circulation 2001, 104, 2386-2387. [CrossRef]

17. Mackness, B.; Davies, G.K.; Turkie, W.; Lee, E.; Roberts, D.H.; Hill, E.; Roberts, C.; Durrington, P.N.; Mackness, M.I. Paraoxonase status in coronary heart disease: Are activity and concentration more important than genotype? Arterioscler. Thromb. Vasc. Boil. 2001, 21, 1451-1457. [CrossRef]

18. Pandey, U.; Kumari, R.; Nath, B.; Ganesh, S.; Banerjee, I.; Hasan, O.M.; Midha, T.; Pandey, S. Association of angiotensin-converting enzyme, methylene tetrahydrofolate reductase and paraoxonase gene polymorphism and coronary artery disease in an Indian population. Cardiol. J. 2011, 18, 385-394.

19. Davies, H.G.; Richter, R.J.; Keifer, M.; Broomfield, C.A.; Sowalla, J.; Furlong, C.E. The effect of the human serum paraoxonase polymorphism is reversed with diazoxon, soman and sarin. Nat. Genet. 1996, 14, 334-336. [CrossRef]

20. Durrington, P.N.; Mackness, B.; Mackness, M.I. Paraoxonase and atherosclerosis. Arterioscler. Thromb. Vasc. Biol. 2001, 21, 473-480. [CrossRef]

21. Rowles, J.; Scherer, S.W.; Xi, T.; Majer, M.; Nickle, D.C.; Rommens, J.M.; Popov, K.M.; Harris, R.A.; Riebow, N.L.; Xia, J.; et al. Cloning and Characterization of PDK4 on 7q21.3 Encoding a Fourth Pyruvate Dehydrogenase Kinase Isoenzyme in Human. J. Boil. Chem. 1996, 271, 22376-22382. [CrossRef]

22. Primo-Parmo, S.L.; Sorenson, R.C.; Teiber, J.; Du, B.N. The Human Serum Paraoxonase/Arylesterase Gene (PON1) Is One Member of a Multigene Family. Genomics 1996, 33, 498-507. [CrossRef] [PubMed] 
23. Clendenning, J.B.; Humbert, R.; Green, E.D.; Wood, C.; Traver, D.; Furlong, C.E. Structural organisation of human PON1 gene. Genomics 1996, 35, 586-589. [CrossRef] [PubMed]

24. Mackness, M.I.; Durrington, P.N.; Mackness, B. How high-density lipoprotein protects against the effects of lipid peroxidation. Curr. Opin. Lipidol. 2000, 11, 383-388. [CrossRef]

25. Lu, H.; Zhu, J.; Zang, Y.; Ze, Y.; Qin, J. Cloning, purification, and refolding of human paraoxonase-3 expressed in Escherichia coli and its characterization. Protein Expr. Purif. 2006, 46, 92-99. [CrossRef] [PubMed]

26. Stevens, R.C.; Suzuki, S.M.; Cole, T.B.; Park, S.S.; Richter, R.J.; Furlong, C.E. Engineered recombinant human paraoxonase (19rHuPON1) purified from Escherichia. coli protects against organophosphate poisoning. Proc. Natl. Acad. Sci. USA 2008, 105, 12780-12784. [CrossRef]

27. Otto, T.C.; Harsch, C.K.; Yeung, D.T.; Magliery, T.J.; Cerasoli, D.M.; Lenz, D.E. Dramatic differences in organophosphorus hydrolase activity between human and chimeric recombinant mammalian paraoxonase-1 enzymes. Biochemistry 2009, 48, 10416-10422. [CrossRef]

28. Brushia, R.J.; Forte, T.M.; Oda, M.N.; La Du, B.N.; Bielicki, J.K. Baculovirus-mediated expression and purification of human serum paraoxonase 1A. J. Lipid Res. 2001, 42, 951-958.

29. Zhu, J.; Ze, Y.; Zhang, C.; Zang, Y.; Lu, H.; Chu, P.; Sun, M.; Qin, J. High-level expression of recombinant human paraoxonase $1 \mathrm{Q}$ in silkworm larvae (Bombyx mori). Appl. Microbiol. Biotechnol. 2006, 72, 103-108. [CrossRef]

30. Telford, G.; Wheeler, D.; Williams, P.; Tomkins, P.T.; Appleby, P.; Sewell, H.; Stewart, G.S.A.B.; Bycroft, B.W.; Pritchard, D.I. The Pseudomonas aeruginosa Quorum-Sensing Signal Molecule N-(3-Oxododecanoyl)1-Homoserine Lactone Has Immunomodulatory Activity. Infect. Immun. 1998, 66, 36-42.

31. Aharoni, A.; Gaidukov, L.; Khersonsky, O.; Mc, Q.G.S.; Roodveldt, C.; Tawfik, D.S. The 'evolvability' of promiscuous protein functions. Nat. Genet. 2005, 37, 73-76. [CrossRef]

32. Ozer, E.A.; Pezzulo, A.; Shih, D.M.; Chun, C.; Furlong, C.; Lusis, A.J.; Greenberg, E.P.; Zabner, J. Human and murine paraoxonase 1 are host modulators of Pseudomonas aeruginosa quorum-sensing. FEMS Microbiol. Lett. 2005, 253, 29-37. [CrossRef] [PubMed]

33. Jordi, C.; Isabel, P.; Frederic, B.; Jorge, J. Paraoxonases as Potential Antibiofilm Agents: Their Relationship with Quorum-Sensing Signals in Gram-Negative Bacteria. Antimicrob. Agents Chemother. 2011, 55, 1325-1331.

34. Available online: http://www.ncbi.nlm.nih.gov.anduniprot.org/uniprot/096561 (accessed on 3 October 2019).

35. Bar-Rogovsky, H.; Hugenmatter, A.; Tawfik, D.S. Tawfik,. The Evolutionary Origins of Detoxifying Enzymes; The mammalian serum paraoxonases (PONs) relate to bacterial homoserine lactonases. J. Biol. Chem. 2013, 288, 23914-23927. [CrossRef] [PubMed]

36. Siddavattam, D.; Khajamohiddin, S.; Manavathi, B.; Pakala, S.B.; Merrick, M. Transposon-like organization of the plasmid-borne organophosphate degradation (opd) gene cluster found in Flavobacterium sp. Appl. Environ. Microbiol. 2003, 2003. 69, 2533-2539. [CrossRef]

37. Sethunathan, N.; Yoshida, T. A Flavobacterium sp. that degrades diazinon and parathion. Can. J. Microbiol. 1973, 19, 873. [CrossRef]

38. Draganov, D.I. Lactonases with organophosphataseactivity: Structural and evolutionary perspectives. Chem. Biol. Interact. 2010, 187, 370-372. [CrossRef]

39. Ozols, J. Isolation and complete covalent structure of liver microsomal paraoxonase. Biochem. J. 1999, 338, 265-272.

40. Rodrigo, L.; Gil, F.; Hernandez, A.F.; López, O.; Pla, A. Identification of paraoxonase 3 in rat liver microsomes: Purification and biochemical properties. Biochem. J. 2003, 376, 261-268. [CrossRef]

41. Draganov, D.I.; Teiber, J.F.; Speelman, A.; Osawa, Y.; Sunahara, R.; La Du, B.N. Human paraoxonases (PON1, PON2, and PON3) are lactonases with overlapping and distinct substrate specificities. J. Lipid Res. 2005, 46, 1239-1247. [CrossRef]

42. La Du, B.N.; Aviram, M.; Billecke, S.; Navab, M.; Primo-Parmo, S.; Sorenson, R.C.; Standiford, T.J. On the physiological role(s) of the paraoxonases. Chem. Interact. 1999, 119, 379-388. [CrossRef]

43. Getz, G.S.; Reardon, C.A. Paraoxonase, a cardioprotective enzyme: Continuing issues. Curr. Opin. Lipidol. 2004, 15, 261-267. [CrossRef] [PubMed]

44. Furlong, C.E.; Shih, D.M.; Lusis, A.J.; Richter, R.J.; Costa, L.G. Genetic factors in Susceptibility: Serum PON1 variation between individuals and Species. Int. J. 2004, 8, 31-43. [CrossRef]

45. Geldmacher von Mallinckrodt, M.; Diepgen, T.L. The human paraoxonase polymorphism and specificity. Toxicol. Environ. Chem. 1988, 18, 179-196. [CrossRef] 
46. Hegele, R.A.; Connelly, P.W.; Scherer, S.W.; Hanley, A.J.G.; Harris, S.B.; Tsui, L.-C.; Zinman, B. Paraoxonase-2 Gene (PON2) G148 Variant Associated with Elevated Fasting Plasma Glucose in Noninsulin-Dependent Diabetes Mellitus 1. J. Clin. Endocrinol. Metab. 1997, 82, 3373-3377. [CrossRef] [PubMed]

47. Hegele, R.A. Paraoxonase genes and disease. Ann. Med. 1999, 31, 217-224. [CrossRef] [PubMed]

48. Campo, S.; Sardo, A.M.; Campo, G.M.; Avenoso, A.; Castaldo, M.; D'Ascola, A.; Giunta, E.; Calatroni, A.S. Identification of paraoxonase 3 gene (PON3) missense mutations in a population of southern Italy. Mutat. Res. 2004, 546, 75-80. [CrossRef]

49. Sanchez, R.; Levy, E.; Seidman, E.; Amre, D.; Costea, F.; Sinnett, D. Paraoxonase 1, 2 and 3 DNA variants and susceptibility to childhood inflammatory bowel disease. Gut 2006, 55, 1820-1821. [CrossRef]

50. Robertson, K.S.; Hawe, E.; Miller, G.J.; Talmud, P.J.; Humphries, S.E. Human paraoxonase gene cluster polymorphisms as predictors of coronary heart disease risk in the prospective Northwick Park Heart Study II. Biochim. Biophys. Acta 2003, 1639, 203-212. [CrossRef]

51. Sanghera, D.K.; Manzi, S.; Minster, R.L.; Shaw, P.; Kao, A.; Bontempo, F.; Kamboh, M.I. Genetic variation in the paraoxonase-3 (PON3) gene is associated with serum PON1 activity. Ann. Hum. Genet. 2008, 72, 72-81. [CrossRef]

52. Aragonès, G.; Guardiola, M.; Barreda, M.; Marsillach, J.; Beltrán-Debón, R.; Rull, A.; Mackness, B.; Mackness, M.; Joven, J.; Simó, J.M.; et al. Measurement of serum PON-3 concentration: Method evaluation, reference values, and influence of genotypes in a population-based study. J. Lipid Res. 2011, 52, 1055-1061. [CrossRef]

53. Wang, X.; Fan, Z.; Huang, J.; Su, S.Y.; Yu, Q.; Zhao, J.; Hui, R.; Yao, Z.; Shen, Y.; Qiang, B.; et al. Extensive Association Analysis Between Polymorphisms of PON Gene Cluster With Coronary Heart Disease In Chinese Han Population. Arterioscler. Thromb. Vasc. Biol. 2003, 23, 328-334. [CrossRef] [PubMed]

54. Ramji, D.P.; Tadros, M.H.; Hardon, E.M.; Cortese, R. The transcription factor LF-A1 interacts with a bipartite recognition sequence in the promoter regions of several liver-specific genes. Nucleic Acids Res. 1991, 19, 1139-1146. [CrossRef] [PubMed]

55. Richard, O. Hynes. Integrins: Versatility, modulation, and signaling in cell adhesion. Cell 1992, 691, 11-25.

56. Van Kooyk, Y.; van de Wiel-van Kemenade, P.; Weder, P.; Kuijper, T.W.; Fifdor, C.G. Enhancement of LFA-1 mediated cell adhesion by triggering through CD3orCD3 on TLymphocytes. Nature 1989, 342, 811-813. [CrossRef] [PubMed]

57. Marlin, S.D.; Springer, T.A. Purified intercellular adhesion molecule-1 (ICAM-1) is a ligand for lymphocyte function-associated antigen 1 (LFA-1). Cell 1987, 51, 813-819. [CrossRef]

58. Marsillach, J.; Becker, J.O.; Vaisar, T.; Hahn, B.H.; Brunzell, J.D.; Furlong, C.E.; De Boer, I.H.; McMahon, M.A.; Hoofnagle, A.N. DCCT/EDIC Research Group Paraoxonase-3 Is Depleted from the High-Density Lipoproteins of Autoimmune Disease Patients with Subclinical Atherosclerosis. J. Proteome Res. 2015, 14, 2046-2054. [CrossRef]

59. Kumari, P.; Kiran, D.G.; Yash, P.S. Low Paraoxonase 3 activity, circulatory concentration and A99A variants in North West Indian Punjabis; a predictive risk for angiographically proven CAD. Int. J. Non-Commun. Dis. 2017, 2, s-75-AB000R568. Available online: http://www.ijncd.org (accessed on 23 November 2019).

60. Suchocka, Z.; Swatowska, J.; Pachecka, J.; Suchocki, P. RP-HPLC determination of paraoxonase 3 activity in human blood serum. J. Pharm. Biomed. Anal. 2006, 42, 113-119. [CrossRef]

61. Khersonsky, O.; Tawfik, D.S. Structure-Reactivity Studies of Serum Paraoxonase PON1 Suggest that Its Native Activity Is Lactonaset. Biochemistry 2005, 44, 6371-6382. [CrossRef]

62. Gaidukov, L.; Tawfik, D.S. High Affinity, Stability, and Lactonase Activity of Serum Paraoxonase PON1 Anchored on HDL with ApoA-I. Biochemistry 2005, 44, 11843-11854. [CrossRef]

63. Harel, M.; Aharoni, A.; Gaidukov, L.; Brumshtein, B.; Khersonsky, O.; Meged, R.; Dvir, H.; Ravelli, R.B.G.; McCarthy, A.; Toker, L.; et al. Structure and evolution of the serum paraoxonase family of detoxifying and anti-atherosclerotic enzymes. Nat. Struct. Mol. Boil. 2004, 11, 412-419. [CrossRef] [PubMed]

64. Adams, T.B.; Greer, D.B.; Doull, J.; Munro, I.C.; Newberne, P.; Portoghese, P.S.; Smith, R.L.; Wagner, B.M.; Weil, C.S.; Woods, L.A.; et al. The FEMA GRAS assessment of lactones used as a flavour ingredients. The Flavor and Extract Manufacturers' Association. Generally recognized as safe. Food Chem. 1998, 36, 249-278. [CrossRef] 
65. Teiber, J.F.; Xiao, J.; Kramer, G.L.; Ogawa, S.; Ebner, C.; Wolleb, H.; Carreira, E.M.; Shih, D.M.; Haley, R.W. Identification of biologically active d-lactone eicosanoids as paraoxonase substrates. Biochem. Biophys. Res. Commun. 2018, 505, 87-92. [CrossRef] [PubMed]

66. Erdal, B.; Ahmet, B.; Tulin, B.; Tevfik, N. Comparison of serum acetyl hydrolase (PAF-AH) and paraoxonase1(PON1) values between prostate cancer patients and a control group. Kaohsiung J. Med. Sci. 2017, 11, 572-577.

67. Carr, R.L.; Dail, M.B.; Chambers, H.W.; Chambers, J.E. Species Differences in Paraoxonase Mediated Hydrolysis of Several Organophosphorus Insecticide Metabolites. J. Toxicol. 2015, 2015, 1-5. [CrossRef] [PubMed]

68. Aggarwal, G.; Prajapati, R.; Tripathy, R.K.; Bajaj, P.; Iyengar, A.R.S.; Sangamwar, A.T.; Pande, A.H. Towards understanding the catalytic mechanism of human Paraoxonase 1: Site-Specific Mutagenesis at Position 192. PLoS ONE 2016, 11, e0147999. [CrossRef]

69. Le, Q.A.T.; Kim, S.; Chang, R.; Kim, Y.H. Insights into the Lactonase Mechanism of Serum Paraoxonase 1 (PON1): Experimental and Quantum Mechanics/Molecular Mechanics (QM/MM) Studies. J. Phys. Chem. B 2015, 119, 9571-9585. [CrossRef]

70. Rothem, L.; Hartman, C.; Dahan, A.; Lachter, J.; Eliakim, R.; Shamir, R. Paraoxonases are associated with intestinal inflammatory diseases and intracellularly localized to the endoplasmic reticulum. Free Radic. Boil. Med. 2007, 43, 730-739. [CrossRef]

71. Rozenberg, O.; Shih, D.M.; Aviram, M. Paraoxonase 1(PON1) attenuates macrophage oxidative status; studies in PON1 transfected cells and in PON1 transgenic mice. Atherosclerosis 2005, 18, 9-18. [CrossRef]

72. Shih, D.M.; Xia, Y.-R.; Wang, X.-P.; Wang, S.S.; Bourquard, N.; Fogelman, A.M.; Lusis, A.J.; Reddy, S.T. Decreased obesity and atherosclerosis in human paraoxonase 3 transgenic mice. Circ. Res. 2007, 100, 1200-1207. [CrossRef]

73. Shih, D.M.; Gu, L.; Xia, Y.-R.; Navab, M.; Li, W.-F.; Hama, S.; Castellani, L.W.; Furlong, C.E.; Costa, L.G.; Fogelman, A.M.; et al. Mice lacking serum paraoxonase are susceptible to organophosphate toxicity and atherosclerosis. Nature 1998, 394, 284-287. [CrossRef] [PubMed]

74. Ng, C.J.; Bourquard, N.; Grijalva, V.; Hama, S.; Shih, D.M.; Navab, M.; Fogelman, A.M.; Lusis, A.J.; Young, S.; Reddy, S.T. Paraoxonase-2deficiency aggravates atherosclerosis in mice despite lower apolipoprotein-B-containing lipoproteins: Anti-atherogenic role for paraoxonase-2. J. Biol. Chem. 2006, 281, 29491-29500. [CrossRef] [PubMed]

75. She, Z.G.; Chen, H.Z.; Yan, Y.; Li, H.; Liu, D.P. The Human Paraoxonase Gene Cluster as a Target in the Treatment of Atherosclerosis. Antioxid. Redox Signal. 2012, 16, 597-632. [CrossRef]

76. Marsillach, J.; Mackness, B.; Mackness, M.; Riu, F.; Beltrán, R.; Joven, J.; Camps, J. Immunohistochemical analysis of paraoxonases-1, 2, and 3 expression in normal mouse tissues. Free Radic. Boil. Med. 2008, 45, 146-157. [CrossRef]

77. Shih, D.M.; Xia, Y.-R.; Yu, J.M.; Lusis, A.J. Temporal and tissue-specific patterns of Pon3 expression in mouse: In situ hybridization analysis. Single Mol. Single Cell Seq. 2010, 660, 73-87.

78. Michael, M.; Kulkarni, R.N.; Postic, C.; Previs, S.F.; Shulman, G.I.; Magnuson, M.A.; Kahn, C. Loss of Insulin Signaling in Hepatocytes Leads to Severe Insulin Resistance and Progressive Hepatic Dysfunction. Mol. Cell 2000, 6, 87-97. [CrossRef]

79. Lu, H.; Zhu, J.; Zang, Y.; Ze, Y.; Qin, J. Cloning, high level expression of human paraoxonase-3 in Sf9 cells and pharmacological characterization of its product. Biochem. Pharmacol. 2005, 70, 1019-1025. [CrossRef]

80. Reddy, S.T.; Wadleigh, D.J.; Grijalva, V.; Ng, C.; Hama, S.; Gangopadhyay, A.; Shih, D.M.; Lusis, A.J.; Navab, M.; Fogelman, A.M. Human paraoxonase-3 is an HDL-associated enzyme with biological activity similar to paraoxonase-1 protein but is not regulated by oxidized lipids. Arterioscler. Thromb. Vasc. Boil. 2001, 21, 542-547. [CrossRef]

81. Rosenblat, M.; Draganov, D.; Watson, C.E.; Bisgaier, C.L.; La Du, B.N.; Aviram, M. Mouse Macrophage Paraoxonase 2 Activity Is Increased Whereas Cellular Paraoxonase 3 Activity Is Decreased Under Oxidative Stress. Arterioscler. Thromb. Vasc. Boil. 2003, 23, 468-474. [CrossRef]

82. Précourt, L.-P.; Amre, D.; Denis, M.-C.; Lavoie, J.-C.; Delvin, E.; Seidman, E.; Levy, E. The three-gene paraoxonase family: Physiologic roles, actions and regulation. Atherosclerosis 2011, 214, 20-36. [CrossRef]

83. Draganov, D.I. Human PON3, effects beyond the HDL: clues from human PON3 transgenic mice. Circ. Res. 2007, 100, 1104-1105. [CrossRef] [PubMed] 
84. Frishberg, Y.; Toledano, H.; Becker-Cohen, R.; Feigin, E.; Halle, D. Genetic polymorphism in paraoxonase is a risk factor for childhood focal segmental glomerulosclerosis. Am. J. Kidney Dis. 2000, 36, 1253-1261. [CrossRef] [PubMed]

85. Schweikert, E.M.; Devarajan, A.; Witte, I.; Wilgenbus, P.; Amort, J.; Förstermann, U.; Shabazian, A.; Grijalva, V.; Shih, D.M.; Farias-Eisner, R.; et al. PON3 is upregulated in cancer tissues and protects against mitochondrial superoxide-mediated cell death. Cell Death Differ. 2012, 19, 1549-1560. [CrossRef] [PubMed]

86. Shamir, R.; Hartman, C.; Karry, R.; Pavlotzky, E.; Eliakim, R.; Lachter, J.; Suissa, A.; Aviram, M. Paraoxonases (PONs) 1, 2, and 3 are expressed in human and mouse gastrointestinal tract and in Caco-2 cell line: Selective secretion of PON1 and PON2. Free Radic. Boil. Med. 2005, 39, 336-344. [CrossRef] [PubMed]

87. Rozenberg, O.; Howell, A.; Aviram, M. Pomegranate juice sugar fraction reduces macrophage oxidative state, whereas white grape juice sugar fraction increases it. Atherosclerosis 2006, 188, 68-76. [CrossRef] [PubMed]

88. Jarvik, G.P.; Tsai, N.T.; Mc Kinstry, L.A.; Wani, R.; Brophy, V.H.; Richter, R.J.; Schellenberg, G.D.; Hatsukami, T.S.; Furlong, C.E. Vitamin C and E intake is associated with increased paraoxonase activity. Arterioscler. Thromb. Vasc. Biol. 2002, 22, 1329-1333. [CrossRef]

89. Romani, R.; De Medio, G.E.; Di Tullio, S.; Lapalombella, R.; Pirisinu, I.; Margonato, V.; Veicsteinas, A.; Marini, M.; Rosi, G. Modulation of paraoxonase 1 and 3 expression after moderate exercise training in the rat. J. Lipid Res. 2009, 50, 2036-2045. [CrossRef]

90. Ng, C.J.; Bourquard, N.; Hama, S.Y.; Shih, D.; Grijalva, V.R.; Navab, M.; Fogelman, A.M.; Reddy, S.T. Adenovirus-Mediated Expression of Human Paraoxonase 3 Protects Against the Progression of Atherosclerosis in Apolipoprotein E-Deficient Mice. Arterioscler. Thromb. Vasc. Boil. 2007, 27, 1368-1374. [CrossRef]

91. Belteki, G.; Kempster, S.L.; Forhead, A.J.; Giussani, D.A.; Fowden, A.L.; Curley, A.; Charnock-Jones, D.S.; Smith, G.C.S. Paraoxonase-3, a Putative Circulating Antioxidant, Is Systemically Up-Regulated in Late Gestation in the Fetal Rat, Sheep, and Human. J. Clin. Endocrinol. Metab. 2010, 95, 3798-3805. [CrossRef]

92. Boehm, D.; Krzystek-Korpacka, M.; Neubauer, K.; Matusiewicz, M.; Berdowska, I.; Zielinski, B.; Paradowski, L.; Andrzej, G. Paraoxonase-1 status in Crohn's disease and ulcerative colitis. Inflamm. Bowel. Dis. 2009, 15, 93-99. [CrossRef]

93. Baskol, G.; Baskol, M.; Yurci, A.; Ozbakir, O.; Yucesoy, M. Serum paraoxonase-1 activity and malondialdehyde levels in patients with ulcerative colitis. Cell Biochem. Funct. 2006, 24, 283-286. [CrossRef] [PubMed]

94. Abbott, C.A.; Mackness, M.I.; Kumar, S.; Boulton, A.J.; Durrington, P.N. Serum Paraoxonase Activity, Concentration, and Phenotype Distribution in Diabetes Mellitus and Its Relationship to Serum Lipids and Lipoproteins. Arterioscler. Thromb. Vasc. Boil. 1995, 15, 1812-1818. [CrossRef] [PubMed]

95. Ng, C.J.; Shih, D.M.; Hama, S.Y.; Villa, N.; Navab, M.; Reddy, S.T. The paraoxonase gene family and atherosclerosis. Free Radic. Boil. Med. 2005, 38, 153-163. [CrossRef] [PubMed]

96. Tward, A.; Xia, Y.-R.; Wang, X.-P.; Shi, Y.-S.; Park, C.; Castellani, L.W.; Lusis, A.J.; Shih, D.M.; Fisher, C.; MacLean, M.; et al. Decreased Atherosclerotic Lesion Formation in Human Serum Paraoxonase Transgenic Mice. Circulation 2002, 106, 484-490. [CrossRef] [PubMed]

97. Rozenberg, O. Paraoxonase (PON1) deficiency is associated with increased macrophage oxidative stress: Studies in PON1-knockout mice. Free Radic. Boil. Med. 2003, 34, 774-784. [CrossRef]

98. Deakin, S.; Leviev, I.; Guernier, S.; James, R.W. Simvastatin modulates expression of the PON1 gene and increases serum paraoxonase: A role for sterol regulatory element-binding protein-2. Arterioscler. Thromb. Vasc. Biol. 2003, 23, 2083-2089. [CrossRef]

99. Shih, D.M.; Yu, J.M.; Vergnes, L.; Dali-Youcef, N.; Champion, M.D.; Devarajan, A.; Zhang, P.; Castellani, L.W.; Brindley, D.N.; Jamey, C.; et al. PON3 knockout mice are susceptible to obesity, gallstone formation, and atherosclerosis. FASEB J. 2015, 29, 1185-1197. [CrossRef]

100. Zhang, C.; Peng, W.; Wang, M.; Zhu, J.; Zang, Y.; Shi, W.; Zhang, J.; Qin, J. Studies on protective effects of human paraoxonases 1 and 3 on atherosclerosis in apolipoprotein E knockout mice. Gene Ther. 2010, 17, 626-633. [CrossRef]

101. Peng, W.; Zhang, C.; Lv, H.; Zhu, J.; Zang, Y.; Pang, X.; Zhang, J.; Qin, J. Comparative evaluation of the protective potentials of human paraoxonase 1 and 3 against CCl4-induced liver injury. Toxicol. Lett. 2010, 193, 159-166. [CrossRef] 
102. Peng, W.; Jiang, X.; Haiqin, L.; Zhang, C.; Zhu, J.; Zhang, J.; Zang, Y.; Qin, J. Protective effects of transgene expressed human PON3 against CCl4-induced subacute liver injury in mice. Biomed. Pharmacother. 2009, 63, 592-598. [CrossRef]

103. Leaf, D.A. The effect of physical exercise on reverse cholesterol transport. Metabolism 2003, 52, 950-957. [CrossRef]

104. Kurl, S.; Laukkanen, J.; Niskanen, L.; Rauramaa, R.; Tuomainen, T.; Sivenius, J.; Salonen, J. Cardiac Power During Exercise and the Risk of Stroke in Men. Stroke 2005, 36, 820-824. [CrossRef]

105. Bradamante, S.; Barenghi, L.; Villa, A. Cardiovascular protective effects of resveratrol. Cardiovasc. Drug Rev. 2004, 22, 169-188. [CrossRef]

106. Costa, L.G.; Giordano, G.; Furlong, C.E. Pharmacological and dietary modulators of paraoxonase 1 (PON1) activity and expression: The hunt goes on. Biochem. Pharmacol. 2011, 81, 337-344. [CrossRef]

107. Noll, C.; Dairou, J.; Ripoll, C.; Paul, J.-L.; Dupret, J.-M.; Delabar, J.-M.; Rodrigues-Lima, F.; Janel, N. Effect of red wine polyphenol dietary supplementation on two phase II enzymes in liver of hyperhomocysteinemic mice. Food Chem. Toxicol. 2011, 49, 1764-1769. [CrossRef]

108. Sebai, H.; Sani, M.; Yacoubi, M.T.; Aouani, E.; Ghanem-Boughanmi, N.; Ben-Attia, M. Resveratrol, a red wine polyphenol, attenuates lipopolysaccharide-induced oxidative stress in rat liver. Ecotoxicol. Environ. Saf. 2010, 73, 1078-1083. [CrossRef]

109. Pais, P.; Pogue, S.; Gerstein, H. Risk factors for acute myocardial infarction in Indians: A case-control study. Lancet 1998, 348, 358-363. [CrossRef]

110. Gupta, N.; Kandimalla, R.; Priyanka, K.; Singh, G.; Gill, K.D.; Singh, S. Effect of Resveratrol and Nicotine on PON1 gene expression:in vitro study. Ind. J. Clin. Biochem. 2014, 29, 69-73. [CrossRef]

111. She, Z.-G.; Zheng, W.; Wei, Y.-S.; Chen, H.-Z.; Wang, A.-B.; Li, H.-L.; Liu, G.; Zhang, R.; Liu, J.-J.; Stallcup, W.B.; et al. Human Paraoxonase Gene Cluster Transgenic Overexpression Represses Atherogenesis and Promotes Atherosclerotic Plaque Stability in ApoE-Null Mice. Circ. Res. 2009, 104, 1160-1168. [CrossRef]

112. Devarajan, A.; Shih, D.; Reddy, S.T. Inflammation, Infection, Cancer and All That... The Role of Paraoxonases. Adv. Exp. Med. Biol. 2014, 824, 33-41.

113. Witte, I.; Foerstermann, U.; Devarajan, A.; Reddy, S.T.; Horke, S. Protectors or Traitors: The Roles of PON2 and PON3 in Atherosclerosis and Cancer. J. Lipids 2012, 2012, 342806. [CrossRef]

114. Carlson, C.S.; Heagerty, P.J.; Hatsukami, T.S.; Richter, R.J.; Ranchalis, J.; Lewis, J.; Bacus, T.J.; McKinstry, L.A.; Schellenberg, G.D.; Rieder, M.; et al. TagSNP analyses of the PON gene cluster: Effects on PON1 activity, LDL oxidative susceptibility, and vascular disease. J. Lipid Res. 2006, 47, 1014-1024. [CrossRef]

115. Marsillach, J.; Aragonès, G.; Beltrán, R.; Caballería, J.; Pedro-Botet, J.; Morcillo-Suárez, C.; Navarro, A.; Joven, J.; Camps, J. The measurement of the lactonase activity of paraoxonase- 1 in the clinical evaluation of patients with chronic liver impairment. Clin. Biochem. 2009, 42, 91-98. [CrossRef]

116. Riedmaier, S.; Klein, K.; Winter, S.; Hofmann, U.; Schwab, M.; Zanger, U.M. Paraoxonase (PON1 and PON3) Polymorphisms: Impact on Liver Expression and Atorvastatin-Lactone Hydrolysis. Front. Pharmacol. 2011, 2, 41. [CrossRef]

117. Kim, D.S.; Burt, A.A.; Ranchalis, J.E.; Richter, R.J.; Marshall, J.K.; Eintracht, J.F.; Rosenthal, E.A.; Furlong, C.E.; Jarvik, G.P. Additional Common Polymorphisms in the PON Gene Cluster Predict PON1 Activity but Not Vascular Disease. J. Lipids 2012, 2012, 476316. [CrossRef]

(C) 2019 by the authors. Licensee MDPI, Basel, Switzerland. This article is an open access article distributed under the terms and conditions of the Creative Commons Attribution (CC BY) license (http://creativecommons.org/licenses/by/4.0/). 